\title{
The Financial Accelerator: Evidence from the International Housing Markets*
}

\author{
Heitor Almeida \\ New York University and NBER \\ halmeida@stern.nyu.edu \\ Murillo Campello \\ University of Illinois \\ campello@uiuc.edu \\ Crocker Liu \\ New York University \\ cliu@stern.nyu.edu \\ (This Draft: October 18, 2005)
}

\begin{abstract}
This paper shows novel evidence on the mechanism through which financial constraints amplify fluctuations in asset prices and credit demand. It does so using contractual features of housing finance. Among agents whose housing demand is constrained by the availability of collateral, those who can borrow against a larger fraction of their housing value (achieve a higher loan-to-value, or LTV, ratio) have more procyclical debt capacity. This procyclicality underlies the financial accelerator mechanism described by Stein (1995) and Bernanke et al. (1996). Our study uses international variation in maximum LTV ratios over three decades to test whether (a) housing prices and (b) demand for new mortgage borrowings are more sensitive to income shocks in countries where households can achieve higher LTV ratios. The results we obtain are consistent with the dynamics of a collateral-based financial accelerator in housing markets.
\end{abstract}

JEL classification: G15, E44.

Key words: Financial contracting, financial accelerator, housing prices, collateral constraint, income constraint.

*We thank Adam Ashcraft, Long Chen, Luigi Guiso, Steve Malpezzi, Walter Novaes, Raghuram Rajan, Luigi Zingales, and participants at the CEPR conference on Financial Structure and Monetary Policy Channels (Barcelona, July 2003) for helpful comments and suggestions. We also thank Olimpia Bover, Maria Chiuri, Nathalie Girouard, Tullio Jappelli, Steve Malpezzi, Felipe Morande, Marco Pagano, and Shiawee Yang for kindly providing us with data. The usual disclaimer applies. 


\section{Introduction}

Theoretical research proposes that endogenous developments in the financial markets can greatly amplify the effects of small income shocks through the economy (Kiyotaki and Moore, 1997; and Bernanke et al., 1996, 1999). Bernanke et al. (1996) call this amplification mechanism the "financial accelerator" or "credit multiplier." The key idea behind the financial accelerator is the notion that shocks to the net worth of firms and households have a procyclical effect on their borrowing capacity. This can happen either because the information cost wedge between external and internal finance moves countercyclically (Bernanke and Gertler, 1989), or because a procyclical change in the value of collateralizable assets changes the external financing capacity in the same direction (Kiyotaki and Moore, 1997). Following a positive income shock, agents should be able to raise more external finance and the increase in borrowing capacity would further boost spending. According to this view, the endogenous procyclicality of the external financing capacity of firms and individuals may help explain important features of the business cycle and the transmission of monetary policy.

There is very little evidence on the amplification mechanism that underlies the financial accelerator. Remarkably, the empirical work on the accelerator has avoided the essential task of isolating features of real-world financial contracts that can bring about the hypothesized multiplier effects. Instead, most studies look at firm data to explore one insight behind the accelerator story: income shocks should affect corporate spending when firms have imperfect (or constrained) access to credit. Empirically, the investment spending of financially constrained firms should be more sensitive to changes in net worth than the investment of unconstrained firms (see Hubbard, 1998). Another working hypothesis is that constrained firms' spending and borrowing should fluctuate relatively more in the aftermath of monetary and other macro shocks (Gertler and Gilchrist, 1994). Unfortunately, while comparisons between constrained and unconstrained firms might show whether one group's investment is more dependent on income and net worth, they may not identify whether differences in spending stem from an endogenous financial mechanism. Because constrained firms are more dependent on internal funds for investment, they should be more sensitive to a shock that affects income and net worth even when the shock has no endogenous, pro-cyclical effect on their borrowing capacity. Recent research has further argued that the differential investment-income sensitivity of firms that are often seen as "constrained" - typically small and young — can be explained by models that ascribe no role to financial constraints (e.g., Gomes, 2001; and Alti, 2003).

How can one identify whether there is an independent spending effect coming from an endogenous change in financing capacity following an income or wealth shock? The theory suggests that the effect 
of an income shock on constrained agents' spending should be greater when debt capacity is procyclical. In this vein, economists have tried to "quantify" the overall magnitude of the amplification effect for firms with (presumably) procyclical net worth. ${ }^{1}$ But crucially, this empirical strategy does not revolve around any particular type of financial contracting. An alternative approach is to gauge the degree of procyclicality in agents' financing capacity and then pin down the dynamics of the financial accelerator by looking at cross-sectional differences in the spending responses to economic shocks of strictly constrained, cyclical agents. This entails the examination of a real-world contract used by financially constrained agents. We pursue such an approach in this paper.

The housing market is an ideal laboratory for conducting a test of the accelerator. The crucial feature of housing finance contracts that we explore is that the availability of mortgage credit to households is typically limited to a specific proportion of the value of the house they own or are about to purchase (the maximum loan-to-value, or LTV, ratio). We use the theoretical framework developed by Stein (1995) to understand how the presence of a maximum LTV ratio (which implies a down payment constraint) affects prices in the housing market. Stein shows that a binding down payment constraint can increase the housing-price impact of a shock that changes the fundamentals of the housing market - such as an income shock that changes housing demand - relative to a benchmark case in which such constraints are absent. The excess sensitivity of housing prices is generated by a financial accelerator mechanism: the initial shock changes household wealth through changes in housing prices, this in turn shifts household debt capacity, amplifying the impact of the initial shock on demand and prices, and so forth. These feedback effects eventually die out, but they can have long-lasting effects.

It is easy to illustrate our main working hypothesis using the constrained housing market equilibrium characterized by Stein (1995). Suppose that constrained households receive a positive income shock that boosts housing prices. Clearly, the higher the LTV ratio that households can achieve (i.e., the lower the down payment requirement), the higher the associated increase in their borrowing capacity that is generated by the ensuing increase in prices. The procyclical increase in borrowing capacity should itself allow households to further increase housing spending, amplifying the collateralbased spending cycle. If an accelerator effect is present, then housing prices should respond more to the initial income shock when the maximum LTV is high. In this fashion, the relation between LTV ratios and the income sensitivity of housing prices provides for a direct test of the endogenous mechanism underlying the financial accelerator: the impact of shocks to household income on housing prices is amplified by the higher marginal opportunity to borrow associated with a high loan-to-value ratio.

\footnotetext{
${ }^{1}$ This is the spirit of the simulations in Bernanke et al. (1999); see also Carlstrom and Fuerst (1997).
} 
Testing this hypothesis requires some degree of exogenous variation in borrowing constraints (i.e., in LTV ratios). Fortunately, data from international housing markets can be used to test the accelerator theory. To give a concrete example of what we have in mind, consider a country in which housing finance is not well-developed, such as Italy, where historical maximum LTV ratios do not exceed $60 \%$. On the other hand, take a country such as the UK, where LTV ratios averaged $90 \%$ in the last two decades. The accelerator argument suggests that so long as the collateral constraint is binding in both countries, the housing credit multiplier would be much stronger in the UK than in Italy. ${ }^{2}$ Simply put, the collateral-based accelerator story that we examine predicts that, because households in high LTV countries have more procyclical debt capacity, housing prices should be more sensitive to income shocks in the UK than in Italy. We are able to pursue a testing strategy of this sort using a unique set of data on international housing that we have assembled. To our knowledge, this is the most extensive data bank of this type.

The accelerator mechanism of Stein (1995) has a second testable implication. The theory predicts that the housing demand shocks are amplified through changes in the demand for mortgage debt. To wit, if the effect of LTV ratios on housing price dynamics is generated by a credit multiplier, then new mortgage borrowings should also be more sensitive to housing demand shocks in countries with higher maximum LTV ratios. International data on mortgage borrowings allow us to test this second hypothesis.

Finally, our study further characterizes the financial accelerator by developing a third testable hypothesis. This hypothesis arises from the existence of an additional borrowing constraint in mortgage markets: the income (or affordability) constraint. The income constraint stems from real-world features of mortgage contracts that limit the yearly amount of housing expenditures associated with the loan (mortgage payments plus taxes and insurance) to a certain fraction of the household's yearly income. For our purposes, the key difference between the collateral and the income constraints is that only the former type of constraint gives rise to a credit multiplier. To wit, if the income constraint binds, then a household's marginal opportunity to borrow depends positively on its future income stream. On the other hand, the marginal ability to borrow under income constraints does not increase with the current value of the housing unit. The upshot of integrating both types of constraints on household spending in a financial accelerator model is the observation that whenever the income constraint binds, the positive relation between maximum LTV ratios and the sensitivity

\footnotetext{
${ }^{2}$ Note that one could argue that collateral constraints might become less important in the UK, because high maximum LTV ratios (low down payment requirements) allow a greater fraction of the households to become unconstrained. We incorporate this possibility in our empirical tests (see Section 4.4).
} 
of housing prices to income should vanish. In other words, recognizing this additional constraint provides for yet another layer of contrasts that we can use to identify the accelerator.

Disentangling the effects of the income and collateral constraints in housing markets is not a trivial task. ${ }^{3}$ Our empirical strategy explores well-known characteristics of international housing markets to identify situations in which the income constraint is more likely to bind. In particular, we conjecture that the income constraint is more likely to bind when the price of a typical housing unit is high vis-à-vis the household disposable income (high "price-to-income ratio"). Cross-country differences in price-to-income ratios - engendered, for example, by demographic and geographic factors - introduce exogenous variation in housing affordability. ${ }^{4}$ We expect that if the relation between price sensitivities and the LTV ratio are driven by the collateral constraint, then it should be especially strong in countries with more affordable housing.

The evidence of this paper provides support the financial accelerator theory. First, our tests show that housing prices are indeed more sensitive to income shocks in countries with higher maximum LTV ratios. Our estimates indicate that in countries like the UK, where the LTV ratio is around $90 \%$, housing prices decrease by more than $1.2 \%$ in the first year following a $1 \%$ decrease in per capita GDP. On the other hand, in countries such as Italy, where the LTV ratio is around $60 \%$, housing prices decrease by only $0.8 \%$ following a $1 \%$ decrease in per capita GDP. Second, fleshing out the financing mechanism underlying the accelerator, we find evidence that new mortgages responses to household income shocks are also increasing in maximum LTV ratios. Finally, and consistent with our conjecture about the joint role of income and collateral constraints, we find that the relation between LTV ratios and income sensitivities is stronger in countries where housing is cheaper relative to household disposable income.

Our analysis explicitly recognizes a number of alternative factors that could influence the results we report. For example, we control for variables that are likely to be correlated with maximum LTV ratios and that could also explain the cross-country differences in income sensitivities, such as economic development and the propensity for homeownership. In particular, we find that the housing price effect of the LTV ratio remains after expunging the component that is explained by economic development and homeownership. We also explicitly consider the potential for simultaneity biases in our tests and use an alternative approach in which LTV ratios are instrumented with proxies for

\footnotetext{
${ }^{3}$ Unfortunately, we are not aware of the existence of historical data on maximum ratios of mortgage payments to household income for countries other than the US.

${ }^{4}$ E.g., in our data, Singapore is an expensive housing country, while the US is classified as having cheap housing. The difference in housing affordability between these two countries is likely to be a function of their demographic and geographic characteristics. Similar patterns can be seen across countries such as Switzerland and Japan on the one hand, and Canada and Australia on the other.
} 
financial development (e.g., proxies for the quality of the judicial system and of accounting standards). Importantly, the panel structure of our data set allows us to control for time- and country-fixed effects.

Our paper is related to several different strands of literature. We have already explained the relation between our hypotheses and Stein's (1995) model of housing price dynamics. Our analysis also borrows from Lamont and Stein (1999), who examine the sensitivity of housing prices to household income across US cities. Using data from the US, they find that housing prices are more sensitive to changes in city-level GDP in years when homeowners in a particular city have high debt (a proxy for liquidity constraints). Our study, in contrast, uses international variation in maximum LTV ratios and in price-to-income ratios to identify procyclicality in debt capacity. Importantly, the key housing finance variable we use (the maximum LTV ratio) is conceptually different from household's existing leverage. The maximum LTV ratio represents the marginal opportunity to borrow as a function of the value of housing, while household's leverage is an endogenous variable determined by past borrowing decisions and planned future spending. ${ }^{5}$ Finally, Lamont and Stein do not examine the sensitivity of new mortgages to income shocks, and they do not incorporate an income constraint in their analysis.

The current paper also adds to the literature that examines the effects of financial development and financial market liberalization. Existing papers focus primarily on the effects of financial development and liberalization on the corporate sector and on overall growth rates (e.g., Demirgüç-Kunt and Maksimovic, 1998; Rajan and Zingales, 1998; and Bekaert et al., 2005). ${ }^{6}$ However, household behavior and housing markets are also likely to be affected by cross-country variations in financial development. Related evidence of such effects are found in Jappelli and Pagano (1989, 1994), who study the relation between financial development and macroeconomic variables, such as savings and the consumption. Though not studying the accelerator, these authors use maximum LTV ratios as a measure of financial constraints on households exactly as we do - higher LTV ratios are associated with higher debt capacity and less financial constraints on households. Our results indicate that financial development is a contributing factor to the real-side effects of the financial accelerator. Specifically, they help identify a mechanism through which financial development and liberalization seem to magnify fluctuations in housing prices: when financial development is associated with lower borrowing constraints (higher LTV ratios) the financial accelerator becomes stronger.

The role of financial constraints in housing markets has been examined by a few theoretical papers besides Stein (1995). Ortalo-Magné and Rady (2005), for example, consider the effects of

\footnotetext{
${ }^{5}$ While highly levered households are probably more constrained than less levered households, it is hard to argue that households in the UK are more financially constrained than those in Italy.

${ }^{6}$ See Levine (1997) for a survey of the literature on financial development.
} 
an interaction between household heterogeneity and a collateral-type constraint on housing price fluctuations. Their model features an amplification mechanism that relates to the one we seek to empirically identify in this paper: an income shock gets amplified through its impact on the ability of constrained (young) households to afford down payments. Similarly to Stein, their model predicts that housing prices should initially over-react to income shocks.

The remainder of the paper is organized as follows. Section 2 develops our empirical hypotheses. In Section 3, we provide a detailed description of the international housing markets data we use in the study. In Section 4, we present our empirical results. Section 5 concludes the paper.

\section{The Roles of Collateral and Income Constraints on Housing Price Fluctuations}

We build on the theoretical framework of Stein (1995) to develop our hypotheses about the effect of collateral and income constraints on housing prices. Stein models the equilibrium of the housing market under the assumption that a minimum down payment is required for the purchase of a new home. Specifically, if the value of a new home is equal to $P$, then a household must contribute at least a fraction $\tau$ of this value to buy the new home. The down payment constraint means that although the household can raise mortgage debt against the value of its housing wealth, the value of the mortgage loan that can be raised cannot be higher than a fraction $\lambda(=1-\tau)$ of $P$.

The parameter $\lambda$ can be interpreted as the maximum loan-to-value (LTV) ratio. The higher the $\lambda$, the easier it is for a household to borrow in order to finance spending. In the real-world, this parameter depends on variables such as the costs of enforcing and disposing of collateral, regulations about housing finance, and the amount of information creditors have about borrowers. ${ }^{7}$ The fact that the $\lambda$ can be lower than 1 represents a credit quantity (collateral) constraint on households. ${ }^{8}$

Stein characterizes the effects of the down payment constraint on the comparative statics of the model and shows that a binding constraint amplifies the effects of shocks to housing demand on equilibrium housing prices, relative to a benchmark case with no down payment constraints. This amplification effect is created by a "credit multiplier." A shock that increases housing prices, for example, also increases households' borrowing capacity, because the ability to raise mortgage debt is directly linked to the value of housing through the maximum loan-to-value ratio. As the increase in borrowing capacity shifts out the demand for housing, the impact of the initial shock is amplified, and housing

\footnotetext{
${ }^{7}$ See Japelli and Pagano (1994) for a detailed discussion. Spiegel (2001) endogenizes down payment requirements, and argues that LTV ratios can be used to forecast future housing returns.

${ }^{8}$ There is ample evidence from micro data that down payment requirements constrain household behavior. Stein (1995), Genesove and Mayer (1997), and Ortalo-Magné and Rady (2005) provide references and discussion.
} 
prices increase even more, boosting household wealth and borrowing capacity further, and so on.

One implication of the mechanism described by Stein is that the price-financing amplification effect is increasing in the change in borrowing capacity that follows the initial shock. To see this, consider an extreme case in which households need to pay for the home entirely with their own funds, that is, a case in which the maximum LTV ratio is zero. In this case, despite the extreme nature of the credit constraint, there is no multiplier effect being transmitted from the change in housing prices into changes in borrowing capacity — the latter is always equal to zero. The total change in housing prices will then be limited to the effect of the initial shock. In contrast, if the maximum LTV ratio is high, a change in housing prices will have a large effect on borrowing capacity, kickstarting the amplification mechanism. This discussion summarizes to the first implication that we seek to test in this paper:

Implication 1. If the collateral constraint is binding, then the sensitivity of housing prices to shocks to housing demand should be increasing in the maximum LTV ratio available to households.

Besides testing this central implication, our analysis aims at providing evidence for the specific mechanism that explains the link between LTV ratios and housing price fluctuations. According to the theory, when the household is collateral-constrained, the effect of a demand shock is amplified by the associated change in borrowing capacity, and this amplification effect is larger the higher is the maximum LTV ratio. If this argument is correct, then new collateral-based borrowings by households should also be more sensitive to demand shocks in countries with high LTV ratios:

Implication 2. If the collateral constraint is binding, then the sensitivity of new mortgage borrowings to shocks to housing demand should be increasing in the maximum LTV ratio available to households.

The amplifying effect of a higher loan-to-value ratio is conditional on the down payment constraint continuing to bind for the higher LTV ratios. If the maximum LTV ratio becomes so high that the household can easily afford the minimum down payment on the house, then we effectively revert to the benchmark case of no constraints in Stein's model. In this benchmark case, the effect of the shock is again limited to the effect of the change in fundamentals, given that borrowing capacity is inconsequential for housing demand. Our empirical analysis explicitly addresses the possibility that households might be largely unconstrained in high maximum LTV countries.

In addition, it is possible that the collateral constraint is not binding even in situations in which the maximum loan-to-value ratio is relatively low. This possibility arises from the fact that in 
real-world mortgage contracts households face an additional constraint that limits the amount of debt that they can raise against the house: the income, or affordability constraint. The affordability constraint essentially limits the yearly amount of expenditures associated with the mortgage contract (loan payments plus property taxes and insurance) to a certain fraction of the household's expected future yearly income. In the US, this fraction is around $28 \%$.

The presence of income constraints means that households might be financially constrained even if they haven't reached the maximum loan-to-value ratio. A simple example can illustrate this possibility. Suppose that the value of the desired housing unit is equal to 100, and the maximum loan-to-value ratio is $70 \%$. Suppose, in addition, that the household's current wealth level is equal to 30 , so that it can afford the required down payment. In order to qualify for the loan, however, the household's future labor income must be $\frac{1}{0.28}$ times greater than the required level of housing expenditures associated with the loan of 70 (assuming US income limits). If we assume that yearly housing expenditures amount to $10 \%$ of the value of the mortgage, then expected future household income must be higher than 25, or else the household will not qualify for the loan. In such a case, the household's demand for housing would be constrained, but not by the collateral constraint. ${ }^{9}$

Stein's model does not explicitly treat the idea of an income constraint. However, it is easy to gauge the implications of such a constraint in the context of the amplification mechanism described above. Essentially, if the income constraint binds (instead of the collateral constraint), then the selfreinforcing mechanism that links changes in housing prices to changes in borrowing capacity should vanish. To wit, when the income constraint binds, the household's marginal debt capacity will increase with future income, but it will no longer increase with the value of the housing unit. ${ }^{10}$ Because the collateral-based amplification effect goes away, the link between maximum loan-to-value ratios and housing price fluctuations should disappear. This discussion summarizes the third implication that we seek to test in the empirical analysis:

Implication 3. The effect of the maximum LTV ratio on the sensitivity of housing prices to housing demand shocks is driven by country-years in which the income constraint is less likely to bind.

We discuss the details of the tests of our three hypotheses shortly. First, however, we describe the data that we use to test our predictions. This is done in the next section.

\footnotetext{
${ }^{9}$ For example, if expected future income is equal to 15 , the household can only afford a loan of 42, and thus the maximum amount that the household can pay for the housing unit is $42+30=72$.

${ }^{10}$ In our example, if expected future income is equal to 15 , then the maximum loan amount equals 42 , irrespective of the value of the housing unit.
} 


\section{Data Description}

We gather data suitable for our analysis from a total of 26 countries over the 1970-1999 period (see Table 2 for the list of countries). The housing price data are summarized in Table 1 together with the data on per capita GDP (the main driving variable in our empirical tests) and annual new mortgages (which we use to assess the credit effects of the accelerator). We use yearly changes in the logs of GDP and housing prices, deflating the data with consumer price index series taken from the IMF's International Finance Statistics database. New mortgages are expressed as a fraction of nominal GDP. The data on housing prices and new mortgages are hand-collected from a number of different sources, while the GDP data are taken from the IMF financial statistics. We list all of our data sources and provide detailed information about the different indices used in the Appendix. ${ }^{11}$ Our sample has 754 country-year observations.

- insert Table 1 here -

Table 2 displays country-level data on maximum LTV, homeownership, and housing pricedisposable income ratios. Each of these series is relevant for our analysis. The maximum LTV ratio is the empirical counterpart of the parameter $\lambda$ described in Section 2. Most of the LTV data are taken from Jappelli and Pagano $(1989,1994)$, who also use the maximum LTV ratio as a measure of the availability of credit to households in international housing markets. Those authors argue that the maximum LTV ratio is a direct measure of constraints on households that is comparable across countries. We were able to augment the Jappelli and Pagano data set using data from Chiuri and Jappelli (2000), and by looking into the sources cited therein. We collect additional data on LTV ratios from a number of other sources as well (see the Appendix). Table 2 shows that maximum LTV ratios vary significantly around the world. Developing countries, such as Korea and Taiwan, generally have lower LTV ratios (as low as 30\%). However, there is variability even among developed economies, as evidenced by the case of Italy, where the LTV ratio is 60\% during the 1990's, and the UK, where the LTV is $95 \%$ during that same period. Maximum LTV ratios seem to vary less over time within a country, but a number of countries register significant time variation in LTVs (examples are Belgium, Denmark, Germany, Hong Kong, Sweden, Spain, and the UK). This allows us to explore both within- and cross-country variations in the dynamics of the financial accelerator.

\section{- insert Table 2 here -}

\footnotetext{
${ }^{11}$ The data used in this paper are available from the authors upon request.
} 
Our empirical analysis uses homeownership to control for differences in the size of the rental market. The homeownership ratio represents the proportion of home owners as a fraction of total households in a country. Country-level homeownership data were hand-collected from several sources. Table 2 suggests that these country series remain relatively stable over time.

In Section 2, we argue that the effect of the maximum LTV ratio on income sensitivities should be significant when the collateral constraint is binding. However, it is also possible that the income constraint binds, which could dampen the positive association between LTVs and price-income sensitivities. Identifying which of those constraints is most likely to bind in each of the countries we study is not an easy task. Clearly, the income constraint is more likely to bind when the maximum fraction of mortgage expenditures (loan service, taxes, and insurance) to expected household income is low. But, unfortunately, we do not have mortgage contract data on income limits for countries other than the US.

In order to implement a test of the income constraint we need a source of cross-country variation that is exogenous and that changes the likelihood that the income constraint will bind. In the absence of data on mortgage-income limits, we conjecture that the income constraint will be more likely to bind when the typical housing unit in the country is high ("expensive") when compared to the disposable income of a typical household. Specifically, we employ the ratio of the price of a typical dwelling unit to yearly median household disposable income (price-income ratio) to gauge the likelihood that the income constraint binds in a given country. This proxy seems to suit our needs well: if housing is expensive relative to households' disposable income, then mortgage expenditures should be more likely to reach the households' income constraint. Noteworthy, there is a large cross-country variation in the ratio of the value of a typical housing unit to disposable income (Table 2). In countries such as Switzerland and Singapore, typical housing units are substantially more expensive than in other countries, such as the US and Canada. Importantly, these differences seem to be driven by factors such as country geography and size as well as population growth and density, and thus are at least partially exogenous.

\section{Empirical Tests}

Our baseline tests focus on cross-country-year differences in the sensitivity of housing prices to income shocks. According to the financial accelerator hypothesis, that sensitivity should be especially strong when the maximum LTV ratio is high, because of the endogenous change in debt capacity following a positive shock to income. In addition, new mortgage borrowings should also be more 
sensitive to income shocks if the maximum LTV ratio is high. Finally, the income constraint suggests that the relation between LTV ratios and income sensitivities should be stronger in countries with relatively cheap housing (i.e., low price-income ratios). Finding that these patterns are present in the data is consistent with evidence of the financial accelerator in housing markets.

\subsection{Housing price dynamics}

We need a benchmark empirical model of housing price dynamics to test our hypotheses. Following Lamont and Stein (1999), we use the log change in the housing price index as the endogenous regressor in our baseline model. Besides including current household income in our model, we look at the literature for additional determinants of housing prices. For instance, there is ample evidence of a consistent autoregressive pattern in housing prices. There is positive autocorrelation at short lags (Poterba, 1991; and Lamont and Stein, 1999), but negative serial correlation at longer lags (Case and Shiller, 1990; and Lamont and Stein, 1999). This pattern has been shown to hold in international data as well (see Englund and Ioannides, 1997). We experiment with the use of these lag structures in turn.

In Table 3 we pool the sample in a panel regression and search for a model to fit our data on housing prices. Column (1) shows that real housing prices are indeed correlated with real current income (proxied by real per capita GDP). Two additional lags of per capita GDP are also significant when no other variables are included in the regression, as shown in column (2). Columns (3) and (4) show that there is positive price autocorrelation at short lags, but negative autocorrelation at longer lags (long-term reversal). This is true both with and without the inclusion of country effects. ${ }^{12}$

$\overline{\text { - insert Table } 3 \text { here }-}$

Column (5) adds other macroeconomic variables to the model of column (3). Both the real interest rate and the inflation rate have negative effects on housing prices, but their effects are not always significant. Finally, in columns (6) and (7) we use the empirical model proposed by Lamont and Stein (1999) in their study of housing price dynamics in US cities. Essentially, they replace longer lags of price and income changes with the start-of-period ratio of price to per capita income (Price $_{t-1} /$ Income $\left._{t-1}\right)$. As in Lamont and Stein, column (6) shows that longer lags of price and income become insignificant once we include the lagged ratio of price to per capita income. The more parsimonious specification of column (7) seems to capture well the effects of the longer lags.

\footnotetext{
${ }^{12}$ Following the standard approach in the literature, most of our models are estimated via OLS and include both lagged dependent variables and fixed effects (see, e.g., Lamont and Stein, 1999). We, however, recognize the potential for biases in this procedure, and later emphasize results from the Arellano-Bond dynamic panel GMM estimator.
} 
In what follows, we introduce LTV ratios and income constraints in our analysis, using, alternatively, the specifications in columns (1), (3), (4), (5), and (7) of Table 3. This approach might seem tedious, but it will demonstrate that our findings do not hinge on the selection of a particular specification for housing price dynamics.

\subsection{Collateral constraints and the income sensitivity of housing prices}

We introduce collateral constraint effects in our analysis by allowing the price-sensitivity of income to vary according to the maximum LTV ratio (Implication 1). This amounts to augmenting our empirical models by adding an intercept term for the LTV ratio and another term capturing the interaction between LTV and per capita GDP growth. When we use multiple lags of GDP growth, we interact the LTV ratio with all of those lags, besides the current GDP growth (lag 0). This approach will capture the effect of the accelerator even if it takes longer for it to feed through the economy. We then test whether an increase in LTV increases price-income sensitivities by testing whether the parameters on those interaction terms are significantly greater than zero.

Table 4 presents one of the main set of results of our paper. Column (1) shows that the correlation between changes in housing prices and changes in household income is indeed higher in countries with higher maximum LTVs. The positive effect of the LTV ratio remains after we include further lags of price and income in the specification, as shown in column (2). The sum of the interaction terms of the LTV with the current and past lags of the change in income is positive and significant at the $1 \%$ level. When we include country effects in the model the sum of the interaction terms increases (see column (3)). Column (4) shows that the inclusion of inflation and interest rates in the specification reduces the effect of the LTV ratio, but the interaction effects are still positive and significant. Finally, the interaction of the LTV ratio with the current change in income is also significant ( $p$-value of $8 \%$ ) when we use the Lamont and Stein specification. This last specification makes it easier to assess the implied magnitude of the effect of the LTV ratio on income sensitivities. The coefficient returned for $\Delta \log (\text { Income })_{t} \times L T V_{t}$ suggests that if the LTV goes from 0.60 to 0.90, the income-price sensitivity increases from 0.84 to 1.23 . These estimates imply, for example, that a $2 \%$ drop in per capita GDP will depress housing prices by some $1 \%$ more in the UK than in Italy.

$$
\text { - insert Table } 4 \text { here - }
$$

Table 5 reports the results we obtain after imposing several modifications to our basic empirical models. For brevity, we use the specification with three lags of income and prices (columns (2) and 
(3) of Table 4) as a benchmark. ${ }^{13}$

$\overline{\text { - insert Table } 5 \text { here }-}$

Our interpretation of the positive correlation between the LTV ratio and the income sensitivity of housing prices is that this effect is driven by differences in the availability of mortgage finance to households in different countries. To provide further evidence that our results are indeed driven by differences in financial constraints (as opposed to some trivial simultaneity story), we adopt an instrumental variables approach. In particular, we instrument the LTV ratio in our model with variables that we expect are related to the level of financial development across countries. In countries with higher financial development it should be easier for both firms and households to raise outside finance. In the context of mortgage finance, a higher level of financial development should arguably be reflected in the availability of higher LTV ratios for households.

Our set of instruments for LTV includes the index of accounting standards computed by the Center for International Financial Analysis and Research. Accounting standards have been used as a measure of financial development in Rajan and Zingales (1998), among others. The second variable included in our instrument set is a proxy for the effectiveness of the country's judicial system. This proxy is taken from LaPorta et al. (1998). Arguably, the higher the standards of financial disclosure and the more advanced the judicial system in a country, the easier it is for firms to raise funds from a wider circle of investors. The results in columns (1) and (2) of Table 5 show that the effect of the LTV ratio on income sensitivities actually increases after instrumenting for overall financial development. ${ }^{14}$ This is true both with and without the inclusion of country effects. These results suggest that our previous findings are indeed driven by variables affecting the availability of finance.

To the extent that maximum LTVs and economic development might be correlated, one could argue that the results in Table 4 are not primarily driven by financial development, but simply by cross-country differences in economic development. It is likely that the fraction of wealth spent in housing increases with wealth. Then, it could be the case that richer countries have larger income sensitivities, even if financial constraints are never binding. This provides for an "unconstrained explanation" for the observed pattern in sensitivities. Another possible explanation for our results is that the relation between maximum LTV ratios and income sensitivities is driven by cross-country differences in homeownership. One could argue, for example, that countries with large rental markets

\footnotetext{
${ }^{13}$ Our conclusions are similar when we consider the other specifications featured in Table 4.

${ }^{14}$ Importantly, the first-stage regressions show that our set of instruments — which also include lags of the predetermined regressors in the benchmark specification — and the maximum LTV are strongly positively related. The $R^{2}$ of the first-stage regression is 0.39 .
} 
have lower sensitivities and lower LTV ratios because the rental market helps absorb the effect of an income shock, or because only the wealthiest households own homes in countries with low LTV ratios. If this argument explains our results, then the cross-country differences in income sensitivities we observe should be absorbed by variations in the homeownership ratio.

In columns (3) through (6) we address the relevance of these competing stories by adding timevarying proxies for economic development (levels of per capita GDP in constant international prices) and homeownership to our specification. ${ }^{15}$ In columns (3) and (4) we add the economic development proxy together with all of its interactions with lags of income change (lags 0 through 2). In columns (5) and (6) a similar approach is used to control for homeownership. The results from these tests suggest that neither economic development nor homeownership is robustly related to income sensitivities after controlling for the LTV ratio. ${ }^{16}$ The positive effect of LTV on sensitivities remains mostly unchanged after controlling for homeownership and economic development. The sum of the interaction terms of the income changes with the LTV ratio is positive and significant at better than $5 \%$ test level in 3 of the 4 added specifications; in the remaining specification (column (4)) the sum of the interaction terms is still marginally significant ( $p$-value $<12 \%)$.

In column (7) we estimate our baseline model using the GMM estimator for dynamic panel data proposed by Arellano and Bond (1991). Specifically, we implement the one-step Arellano-Bond estimator with each of the base model variables instrumented by two of their own lags (in levels). As is generally the case, the Arellano-Bond estimator returns coefficients that are smaller than those from the OLS regression. Yet, the effect of the maximum LTV ratio on income sensitivities is still positive and statistically significant (at the $1 \%$ level). ${ }^{17}$

Finally, considering the limitation of our sample size, we provide for a direct check for the concern that our results could driven by observations from one particular country. We do this check by performing a series of GMM estimations of our baseline model in which we disregard data from one of the sample countries at each run. The lowest point estimate we obtain for $\sum_{j=0}^{2} \Delta \log (\operatorname{Income})_{t-j}$ $\times L T V_{t}$ equals 0.56 , which is returned when we exclude Japan from the sample. That estimate is statistically significant at the $3 \%$ level. Eliminating any of the other sample countries returns coefficients that are significant at better than the $1 \%$ level.

\footnotetext{
${ }^{15}$ The coefficients returned for these controls are mostly insignificant and are thus omitted from Table 5 .

${ }^{16}$ Results are similar if we use both of these variables and all of their interactions with LTV together in one specification. The same holds under a more parsimonious approach where we only use the LTV ratio and its interactions with income change in the specification after expunging economic development and homeownership main effects from LTVs (i.e., using a "residual LTV").

${ }^{17}$ The Sargan test statistic associated with the Arellano-Bond estimator of Table $5\left(\chi_{(403)}^{2}=392.1, p\right.$-value=64.2\% $)$ reveals that the null of instrument validity cannot be rejected. Also supporting the adequacy of the estimator is the high $p$-value $(=83.5 \%)$ associated with the test of the null of no second-order autocorrelation in the residuals.
} 


\subsection{Collateral constraints and the income sensitivity of new mortgages}

In Section 2 we argue that if households are collateral-constrained, then the income sensitivity of new mortgage borrowings should also be higher in countries with high LTV ratios (Implication 2). This happens because the credit multiplier is generated by endogenous changes in collateralized debt capacity.

In Table 6 we use total annual new mortgages as a fraction of GDP as an alternative dependent variable for our tests. In the absence of priors about the dynamics of new mortgages, we experiment with a few parsimonious specifications. These include (a) only the current lag (lag 0) of income changes, (b) lags 0 through 2 of income changes, and (c) lags 0 and 1 of income changes plus the startof-period ratio of price to per capita income $\left(\right.$ Price $_{t-1} /$ Income $\left._{t-1}\right)$, as in Lamont and Stein (1999). The results from OLS-FE estimations including these sets of regressors are reported in columns (1) through (6) in Table 6. Looking now at smaller samples, we find evidence that new mortgages respond more to changes in household income when LTV ratios are higher. The interaction between income and LTV is positive in all models we experiment with, and statistically significant at better than the $6 \%$ level in all but one of our specifications.

$\overline{\text { - insert Table } 6 \text { here }-}$

It might be useful to illustrate the differences in responses of new mortgages to income shocks across low and high LTV countries using a structural estimation approach. We do this by estimating a four-equation, two-lag VAR system that includes the change in log per capita GDP, the change in $\log$ CPI, the change in log interest rates, and the log of new mortgages (orthogonalized in this order). Noting that a limited set of countries has enough time series data on mortgages for a VAR estimation, we use Italy to capture the accelerator effect in low LTV countries and the US to illustrate the same effect in high LTV countries. Accordingly, we graph the impulse-response functions of new mortgages to one-standard-deviation shocks to GDP for Italy and the US (all variables are standardized).

Comparisons between the two panels in Figure 1 make it clear that the demand for housing financing increases far more strongly in the US than it does in Italy following a similar positive shock to per capita GDP. Specifically, note that a one-standard-deviation GDP shock is around $2.50 \%$ for both countries. In the US, this leads to an increase in the ratio of new mortgages to GDP of $0.50 \%$ after one year, while in Italy this ratio increases by only $0.11 \%$. Evidence from new mortgages, too, agrees with the accelerator mechanism underlying the dynamics of the relation between income 
shocks and constrained borrowing in housing markets.

$\overline{- \text { insert Figure } 1 \text { here }-}$

\subsection{Are households in high LTV countries financially unconstrained?}

One might wonder whether a significantly large fraction of households in countries with high maximum LTV ratios such as the US or the UK are really constrained by the availability of collateral. After all, down payment requirements that are as low as 5\% might imply that only the poorest and youngest households would be constrained by the size of the down payment. Recall, if households become collateral-unconstrained, the amplification mechanism associated with the financial accelerator would die out. At first sight, this possibility should make it harder for us to find the results that we have reported, given that the absence of collateral constraints reduces the extent of housing price fluctuations (Stein, 1995). However, one could argue that maximum LTV ratios are proxying for other (possibly unobservable) variables that are correlated with the sensitivity of housing prices to income shocks; variables that are unrelated to the financial accelerator mechanism.

A direct way to address this concern about our tests is to check whether the ratio of collateralconstrained households is systematically related to maximum LTV ratios. One empirical proxy for the ratio of households that are subject to binding collateral constraints is the ratio between the average and the maximum LTVs. A high ratio means that a greater fraction of mortgages are close to the maximum allowed. We have data on total outstanding mortgages that can be used to estimate average LTV ratios. ${ }^{18}$ If higher maximum LTVs increase the fraction of households that are unconstrained, then we would expect the ratio of average-to-maximum LTV to be negatively related to maximum LTVs. As it turns out, we find that countries with higher maximum LTVs have higher ratios of average-to-maximum LTVs. The correlation between the ratio of average-to-maximum LTV and the maximum LTV is 0.29 ( $p$-value $<1 \%)$. Moreover, a regression of this ratio on maximum LTVs returns a positive and significant coefficient for maximum LTVs.

Our second take on the proposed alternative story involves testing the sensitivity of our findings to the presence of observations with very high maximum LTV ratios in the sample. Accordingly, we rank observations according to either overall country or country-decade maximum LTV ratios. ${ }^{19}$ For each of these two LTV ranking schemes, we then discard from the sample, alternatively, observations in the top decile, quintile, or quartile of the maximum LTV distribution and then reestimate

\footnotetext{
${ }^{18}$ The average LTV ratio is computed as the ratio of mortgage debt outstanding to the value of owner occupied housing, with the latter equal to the stock of housing times the homeownership ratio times the housing price level.

${ }^{19}$ In the first case, we use the average maximum LTV ratio over our entire 30-year sample to rank the countries.
} 
our baseline specification (both with or without country effects). This procedure allows us to check whether our results are driven by those (potentially "unconstrained") countries with the highest maximum LTVs. All such estimations (a total of 12) return a positive significant relation between LTV ratios and income sensitivities. These findings, too, are inconsistent with the hypothesis that country-years with higher maximum LTVs have more unconstrained households.

\subsection{The income constraint}

The third prediction of Section 2 help us further characterize the collateral-based financial accelerator. In particular, it states that if the relation between price-income sensitivities and the maximum LTV ratio is driven by the collateral constraint, then it should be especially strong in countries where the income constraint is less likely to bind. As we discussed in Section 3, the ratio of the value of a typical housing unit to disposable income can be seen as a proxy for the income constraint. ${ }^{20}$ In countries where housing is more expensive, it is more likely that the income constraint will bind. If our hypothesis is correct, the relation between sensitivities and maximum LTV ratios should be particularly more pronounced in countries with inexpensive housing.

In the final set of tests of our paper, we rank countries according to the distribution of the housing price-disposable income ratio and classify as "expensive" ("cheap") those in the top (bottom) third of this ranking. ${ }^{21}$ We then run separate regressions for the two subsamples. To demonstrate the robustness of our findings, we report outputs from OLS and GMM estimations of our baseline model with three lags of income and prices as well as the results pertaining to the Lamont and Stein (1999) specification.

The results from the subsample regressions are reported in Table 7. Consistent with our hypothesis, there is a broad positive association between the LTV ratio and income sensitivities, but this relation is particularly strong and significant in countries with relatively cheaper housing. This pattern holds steady across the different estimation procedures and empirical specifications that we consider. This last set of results provide further evidence that increases in the maximum LTV ratio increase the sensitivity of housing prices to income because the financial accelerator is stronger when

\footnotetext{
${ }^{20}$ We note that the appropriateness of our proxy depends on a subtle condition: in countries with high price-income ratios, the income constraint must be more likely to bind than the collateral constraint. We believe this condition holds generally. To wit, in a country with expensive housing, households will (on aggregate) also tend to be wealthier, since they own the country's housing stock. This suggests that housing price increases tighten income constraints before they tighten wealth constraints. For example, it is true that an increase in the value of the existing housing stock raises the required down payment for new buyers; however, it also increases the wealth of would-be movers who own houses (see Stein, 1995).

${ }^{21}$ Our main conclusions are insensitive to whether we partition our panel data according to the median income-price ratio or, alternatively, according to quartiles, quintiles, or deciles. As could be expected, the latter partitions produce stronger but noisier estimates.
} 
the LTV is higher and households are collateral-constrained.

$\overline{\text { - insert Table } 7 \text { here }-}$

\section{Concluding Remarks}

This study explore the features that characterize housing finance contracts and international housing markets to provide novel evidence supporting the "financial accelerator." In particular, we use international variation in maximum loan-to-value (LTV) ratios to identify, within a group of constrained agents, those with more procyclical borrowing capacity. Since the procyclicality in the borrowing capacity of constrained agents is the amplification mechanism at the heart of the financial accelerator, our empirical strategy allows us to provide a direct test of the endogenous mechanism that underlies the accelerator. Inspired by the model developed by Stein (1995), we propose three implications of the financial accelerator hypothesis for housing price dynamics. Our empirical results are consistent with these three implications; namely that (a) housing prices are more sensitive to aggregate income shocks in countries with higher maximum LTV ratios; (b) new mortgage borrowings, too, are more sensitive to aggregate income shocks in countries with higher LTVs; and (c) the empirical relation between LTV ratios and income sensitivities is stronger in countries in which the income constraint is less likely to bind. These results indicate that debt capacity is more strongly procyclical in countries with high LTV ratios, and that the procyclicality of debt capacity affects housing price dynamics through a collateral constraint. Our empirical analysis explicitly addresses a number of factors that could potentially influence the results we obtain.

Besides being a nice laboratory to study the economic effects of the financial accelerator, the housing market is also one of the markets where the economic significance of such effects is likely to be high. Previous literature has shown that consumer spending is intimately linked to housing wealth (see, e.g., Case et al., 2001; and Shiller, 2004), that housing investment plays a major role in the business cycle (Mishkin, 1978; and Bernanke and Gertler, 1995), and that housing collateral and house price fluctuations play an important role in explaining time series and cross-sectional variations in asset risk premia (Lustig and Van Nieuwerburgh, 2005). This paper shows that the endogenous effect of the financial accelerator in housing markets help characterize the mechanism through which what seem to be small, localized shocks get amplified and transmitted throughout the economy. 


\section{References}

Alti, Aydoğan, "How Sensitive is Investment to Cash Flow When Financing is Frictionless?" Journal of Finance 58, 2003, pp. 707-722.

Arellano, Manuel and Stephen Bond, "Some Tests of Specification for Panel Data: Monte Carlo Evidence and an Application to Employment Equations," Review of Economic Studies 58(2), April 1991, pp. 277-297.

Bekaert, Geert, Campbell Harvey, and Christian Lundblad, "Does Financial Liberalization Spur Growth," 2005, Journal of Financial Economics, forthcoming.

Barro, Robert and Jong-Wha Lee, "Sources of Economic Growth," Carnegie-Rochester Conference Series on Public Policy 40, June 1994, pp. 1-46.

Bernanke, Ben and Mark Gertler, "Agency Costs, Net Worth, and Business Fluctuations," American Economic Review 79, March 1989, pp. 14-31.

Bernanke, Ben and Mark Gertler, "Inside the Black Box: The Credit Channel of Monetary Policy Transmission," Journal of Economic Perspectives 9(4), Fall 1995, pp. 27-48.

Bernanke, Ben, Mark Gertler and Stephen Gilchrist, "The Financial Accelerator and the Flight to Quality," Review of Economics and Statistics 48, February 1996, pp. 1-15.

Bernanke, Ben, Mark Gertler and Stephen Gilchrist, "The Financial Accelerator in a Quantitative Business Cycle Framework," in Taylor, John B. and Michael Woodford, eds: Handbook of macroeconomics. Volume 1C. Handbooks in Economics, vol. 15. Amsterdam, New York and Oxford: Elsevier Science, North-Holland, 1999, pp. 1341-1393.

Carlstrom, Charles and Timothy Fuerst, "Agency Costs, Net Worth and Business Fluctuations: A Computable General Equilibrium Analysis," American Economic Review 87, December 1997, pp. 893-910.

Case, Karl E., John M. Quigley and Robert J. Shiller, "Comparing Wealth Effects: The Stock Market Versus the Housing Market," NBER Working Paper No. 8606, November 2001.

Chiuri, Maria C. and Tullio Jappelli, "Financial Market Imperfections and Homeownership: A Comparative Study," mimeo, 2000.

Demirgüç-Kunt, Asli and Vojislav Maksimovic, "Law, Finance, and Firm Growth," Journal of Finance 53, 1998, pp. 2107-2137.

Englund, Peter and Yannis Ioannides, "Housing Price Dynamics: An International Empirical Perspective," Journal of Housing Economics 6, June 1997, pp. 119-136.

Genesove, David and Christopher Mayer, "Equity and Time-To-Sale in the Real Estate Equity Market," American Economic Review 87, 1997, pp. 255-269.

Gertler, Mark and Stephen Gilchrist, "Monetary Policy, Business Cycles, and the Behavior of Small Manufacturing Firms," Quarterly Journal of Economics 109(2), May 1994, pp. 309-40.

Gomes, João, "Financing Investment," American Economic Review 91, December 2001, pp. 12631285. 
Hubbard, R. Glenn, "Capital Market Imperfections and Investment." The Journal of Economic Literature 36, March 1998, pp. 193-227.

Jappelli, Tullio and Marco Pagano, "Consumption and Capital Market Imperfections: An International Comparison," American Economic Review 79, December 1989, pp. 1088-1105.

Jappelli, Tullio and Marco Pagano, "Savings, Growth and Liquidity Constraints," Quarterly Journal of Economics 109, February 1994, pp. 83-109.

Kiyotaki, Nobuhiro and John Moore, "Credit Cycles," Journal of Political Economy 105, April 1997, pp. 211-48.

Lamont, Owen and Jeremy Stein, "Leverage and Housing Price Dynamics in US Cities," RAND Journal of Economics 30, Autumn 1999, pp. 498-514.

LaPorta, Raphael, Florencio Lopez-De-Silanes, Andrei Shleifer and Robert Vishny, "Law and Finance," Journal of Political Economy 106, 1998, pp. 1113-1155.

Levine, Ross, "Financial Development and Economic Growth: Views and Agenda," Journal of Economic Literature 35, 1997, pp. 688-726.

Lustig, Hanno and Stijn Van Nieuwerburgh, Housing Collateral, Consumption Insurance and Risk Premia: an Empirical Perspective," 2004, forthcoming, Journal of Finance.

Mishkin, Frederic S., "The Household Balance Sheet and the Great Depression," Journal of Economic History 38(4), December 1978, pp. 918-937.

Ortalo-Magné, François and Sven Rady, "Housing Market Dynamics: On the Contribution of Income Shocks and Credit Constraints," 2005, Review of Economic Studies, forthcoming.

Poterba, James M., "House Price Dynamics: The Role of Tax Policy and Demography," Brooking Papers on Economic Activity 4(2), 1991, pp. 143-183.

Rajan, Raghuram and Luigi Zingales, "Financial Dependence and Growth," American Economic Review 88, June 1998, pp. 559-586.

Shiller, Robert, "Household Reaction to Changes in Housing Wealth," 2004, mimeo.

Spiegel, Matthew, "Housing Return and Construction Cycles," Real Estate Economics 29, Winter 2001, pp. 521-551.

Stein, Jeremy, "Prices and Trading Volume in the Housing Market: A Model with Down Payment Effects," Quarterly Journal of Economics 110, May 1995, pp. 379-406. 


\section{Data Appendix}

This appendix describes in detail several of the data items we use in the paper.

\section{Housing price indices}

Most of the data for developed countries are supplied by Peter Englund, which are the same data used in Englund and Ioannides (1997). Below we refer to this source as "EI". Their data covers the period 1970-1992. We update their data set using the Annual Reports from the Bank of International Settlements (BIS), which give information on the same indices used by Englund and Ioannides. For countries not included in the Englund and Ioannides data set, we use other sources described below. We list all the specific sources for each country, and the information we have about the respective indices.

Australia. EI, and BIS. Weighted average index of prices for all capital cities and other areas; obtained from quarterly national census of home loan approvals, available annually. Updated using the AUEHPI index from the Australian Bureau of Statistics.

Belgium. EI, and BIS. Index based on annual transactions reports on small and medium sized dwellings from entire country, with outliers excluded, available annually.

Canada. EI, and BIS. Average annual transaction prices reported by multiple listing services for entire country, covering $70 \%$ of all transactions. Updated using the New House Price Index from the Statistics Canada, available at http://cansim2.statcan.ca.

Chile. Data provided by Felipe Morande, from Morande, F. and R. Soto (1992) updated by R. Soto. Based on standardized dwellings in the area of Santiago, annual average.

Denmark. EI, and BIS. Average value of single-family homes, including only arms' length sales, available annually.

Finland. EI and BIS. Average price per apartment and terraced houses, obtained per square meter, as recorded by realtors (including $30 \%$ of all transactions), weighted by region, available quarterly.

France. EI and BIS. Index based on BIS' own estimate, based on annual values for the Paris region, adjusted by four-year survey for entire country.

Germany. EI and BIS. Transaction prices per square meter, obtained from realtors for the four largest cities, available annually.

Hong Kong. Index constructed by the Rating and Valuation Department, from the Hong Kong Property Review, data from Chou and Shih (1995), updated using data on the same index available at http://www.info.gov.hk.

Ireland. EI and BIS. Average transactions price for existing homes, based on all loan approvals, available annually.

Israel. Property price index representative of the entire country, from the Social Sciences Data Archive (data used in Bar Nathan et al., 1998), updated using data from the Israel Central Bureau of Statistics (www.cbs.gov.il/srcer.cgi).

Italy. EI and BIS. Average price for new and completely refurbished dwellings in large and middle-sized cities and tourist areas, reported by realtors, available annually.

Japan. Urban Residential Land Price Index, from the Japanese Real Estate Institute, available at www.reinet.or.jp.

Korea. Land Price of Housing, from the Korea Appraisal Board, Appraisal Research \& Development Center, available at www.kreic.com.

Malaysia. IHRM (Malaysian House Price Index \% change from previous year). Data provided by Steve Malpezzi and used in Malpezzi and Mayo (1997), updated using data from the Countrywide's Sourcebook 2000.

Netherlands. EI and BIS. Weighted average sales price for existing single and multi-family homes, reported by realtors, including $50-60 \%$ of all transactions, available annually.

New Zealand. Data from Dalziel and Lattimore (1999), Valuation New Zealand Housing Price Series, average prices of free-hold house sales, adjusted for quality, updated using BIS data.

Norway. EI and BIS. Average sales price of existing homes, weighted by type of dwelling, reported by Property Owner's Association, covering about $50 \%$ of all transactions.

Singapore. Data from Phang and Wong (1997). Value weighted average of current prices of five types of property in five planning districts. Excludes public housing. Updated using the SIPRIRES index of the Singapore Department of Statistics.

Spain. Data provided by O. Bover. Prices per square meter of new dwellings in Madrid, used in Bover (1993). Updated with the Price Index for Existing Dwellings, from Hypostat 1999. 
Sweden. EI and BIS. Index based on owner-occupied one- and two-dwelling buildings, based on reports of title registrations for arm's length transactions, weighted by type of dwelling, available annually.

Switzerland. Real estate price index for 3-5 bedroom single family homes, from the Swiss National Bank (http://www.snb.ch/e/search/index.html).

Taiwan. Median of Housing Prices in Taipei, provided by Shiawee Yang.

Thailand. Real housing price index used in Malpezzi and Mayo (1997). Data provided by S. Malpezzi covering the period from 1970-1986. Updated using the series on Land Price Increases in Bangkok, from the Agency for Real Estate Affairs.

UK. EI and BIS. Index based on survey of all dwellings with building societies mortgages, weighted by type of dwelling, available annually.

US. EI and BIS. Index based on sales price of existing single-family homes, based on realtor reports, adjusted by regional availability of single-family homes and homeowner mobility, available annually.

\section{New mortgages}

Data for net new mortgage lending for Belgium, Denmark, Germany, Ireland, Finland, Netherlands and Spain is from Hypostat 1989-1999, and data for Canada, France, Italy, Japan, Norway, Sweden, UK and US is from the OECD, also used by Girouard and Blondal (2001), and kindly provided to us by Nathalie Girouard.

\section{Maximum LTV ratios}

Data is from Jappelli and Pagano (1994), updated with data from Chiuri and Jappelli (2000). The data is given in 10-year averages. We extended this data as follows: for Denmark, Japan, New Zealand and Norway we assumed the Jappelli and Pagano 1980-1987 data extends to 1990. We took 19911999 data for Denmark and Norway from Maclennan, Muellbauer and Stephens (1998). Singapore 1991-1999 data is from Phang and Wong (1997). The data for Chile, Hong Kong, Korea (1980-1999), Japan (1991-1999), New Zealand (1991-1999) and Switzerland is from the Countrywide's Sourcebook, 1995 and 2000. Malaysia and Thailand 1991-1999 data is from the Asian Development Bank, 1999.

\section{Homeownership ratios}

Data for Australia, Belgium, Canada (1970-1989), France (1970-1980), Germany (1970-1980), Italy (1970-1980), Netherlands (1970-1980), Spain (1970-1980), and Taiwan is from Chiuri and Jappelli (2000). Data for Chile, Denmark, Finland, France (1981-1999), Germany (1981-1999), Hong Kong, Ireland, Italy (1981-1999), Japan, Netherlands (1981-1999), Norway, Sweden and Spain (1981-1999) is from the Countrywide's Sourcebook 2000. Data for Korea and Malaysia is from the Asian Development Bank, 1999. Data for Canada (1991-1999), New Zealand, Singapore, Switzerland, Thailand, UK and US is from the Euromonitor (available at www.euromonitor.com).

\section{Price-income ratios}

The data on personal disposable income is from the Economic Outlook No 70: Annual and Semiannual data (Source: OECD), with the following exceptions: the data for Denmark and Thailand is from DRI-Wefa (http://www.dri-wefa.com/), the data for Taiwan is taken from the Government statistics at http://www.stat.gov.tw. We collected the nominal housing price for a particular year, and then we used the housing price index described above to extrapolate the series for all years. The data for Belgium, Denmark, Finland, France, Italy, Netherlands, Spain and Sweden represents the typical price for a flat of 150 square meters in 1999, and is taken from the Countrywide's Sourcebook 2000. The data for Canada (average price of all dwellings, 1995-1999), Ireland (average new house price for the whole country, 1996-1998), Korea (median price of typical 710 square feet apartment in Seoul in 1990), New Zealand (median price of a home, 1999), UK (Mix-adjusted average house price in 1999), and the US (average existing single family house price from 1990-1999), are also taken from the Countrywide's Sourcebook 2000. Below we list the sources and definitions for the remaining countries:

Australia - typical house price in 1999, from http://www.amp.com.au/au/ampweb.nsf/Content. 
Chile - price of an standardized dwelling in selected areas of Santiago, 1975-1998, from Morande and Soto (1992).

Germany - price of existing detached houses, 1970-1993, from Muelder and Wagner (1998).

Hong Kong - price of a 100 square meter flat, 1982-1992, from Chou and Shih (1995).

Israel - typical apartment price in 1999, from www.jpost.com.

Japan - typical apartment price in 1999, from www.pricechecktokyo.com.

Malaysia- typical price of a single-story detached home in 1998, from www.jpph.gov.my.

Norway - average price of a 150 square meter flat, from Statistics Norway (www.ssb.no).

Singapore - 1999, average house price from Asia Week, www.asiaweek.com.

Switzerland - price of an average 4 bedroom semi-detached house with parking in 1999, from www.expatacess.com.

Taiwan - actual average housing purchase price, 1981-1989, from Lin (1993).

Thailand - 1994-97 average house price, from the Asian Development Bank.

\section{References for Data Appendix}

Asian Development Bank, Mortgage-Backed Securities Markets in Asia, 1999, online publication available at http://www.adb.org.

Bank of International Settlements, Annual Reports no. 64, 65, 66, 67, 68, 69, 70.

Bar Nathan, M., M. Beenstock and Y. Haitovsky, "The Market for Housing in Israel," Regional Science and Urban Economics 28, 1998, pp. 21-49.

Bover, Olympia, "Un Modelo Empirico de la Evolucion de los Precios de la Vivienda en Espana," Investigaciones Economicas 17, 1993, pp. 65-86.

Chou, W.L. and Y.C. Shih, "Hong Kong Housing Markets: Overview, Tenure Choice and Housing Demand," Journal of Real Estate Finance and Economics 10, 1995, pp. 7-21.

Countrywide International, International Union for Housing Finance (IUHF) International Data and Analysis: Countrywide's Sourcebook, 1995, 2000.

Dalziel, Paul and Ralph Lattimore, The New Zealand Macroeconomy: A Briefing on the Reforms. Second edition. Melbourne; Oxford and New York: Oxford University Press, 1996.

European Mortgage Federation, Hypostat 1989-1999: Mortgage and Property Markets in the European Union and Norway, 2000, available online at www.hypo.org.

Girouard, Nathalie and Sveinbjorn Blondal, "House Prices and Economic Activity." OECD Economics Department Working Papers no. 279, 1999.

Lin, C. S., "The Relationship Between Rents and Prices of Owner-Occupied Housing in Taiwan," Journal of Real Estate Finance and Economics 6, 1993, pp. 25-54.

Malpezzi, Stephen and Stephen Mayo, "Getting Housing Incentives Right: A Case Study of the Effects of Regulation, Taxes, and Subsidies of Housing Supply in Malaysia," Land Economics 73, 1997, pp. 372-391.

Morande, Felipe and Raimundo Soto, "Una nota sobre la construcción de series de precios de activos reales: Tierra y Casas en Chile," Revista de Análisis Económico 7, 1992, pp. 169-178.

Muelder C. and M. Wagner, "First Time Home-Ownership in the Family Life Course: A West German-Dutch Comparison," Urban Studies 35, 1997, pp. 687-713.

OECD, Economic Outlook No 70: Annual and Semiannual Data.

Phang, Sock-Yang and Wing-Keung Wong, "Government Policies and Private Housing Prices in Singapore," Urban Studies 34, 1997, pp. 1819-1829. 
Table 1: Summary Statistics of Housing Price Changes, Income Growth, and New Mortgages

This table displays summary statistics for housing prices chages, income growth, and new mortgages for 26 countries over the 1970-1999 period. $\Delta \log$ (Price) is the log change in the real housing price index. $\Delta \log ($ Income $)$ is the log change in real per capita GDP. New mortgages are net new lending against mortgage in residential property divided by nominal GDP. GDP, population, and inflation data are from the IMF's International Financial Statistics. The housing price and new mortgage data are described in the Appendix.

\begin{tabular}{lcccccccc}
\hline \hline & Mean & Std. Dev. & Pct 5 & Pct 25 & Median & Pct 75 & Pct 95 & N. Obs \\
\hline \multirow{2}{*}{$\log ($ Price $)$} & 0.020 & 0.116 & -0.150 & -0.034 & 0.015 & 0.072 & 0.210 & 718 \\
$\Delta \log ($ Income $)$ & 0.030 & 0.045 & -0.033 & 0.007 & 0.027 & 0.051 & 0.102 & 754 \\
New Mortgages & 0.030 & 0.022 & 0.002 & 0.015 & 0.027 & 0.040 & 0.069 & 278 \\
\hline \hline
\end{tabular}


Table 2: Average Maximum Loan-to-Value (LTV), Homeownership, and Price-Income Ratios by Country-Decade, 1970-1999

Maximum LTV ratios represent the highest mortgage loan that households can get from lenders as a fraction of the value of the property owned. The homeownership ratio is the proportion of homeowners as a fraction of total households. The priceincome ratio is the nominal price of a typical home divided by personal disposable income per capita. All data items are described in the Appendix.

\begin{tabular}{|c|c|c|c|c|c|c|c|c|c|}
\hline \multirow[t]{2}{*}{ Country } & \multicolumn{3}{|c|}{ LTV Ratio } & \multicolumn{3}{|c|}{ Homeown. Ratio } & \multicolumn{3}{|c|}{ Price-Income Ratio } \\
\hline & 70 's & 80 's & 90 's & 70 's & 80 's & 90 's & 70 's & 80 's & 90 's \\
\hline Australia & 0.70 & 0.80 & 0.80 & 0.70 & 0.70 & 0.70 & 10.5 & 8.5 & 9.5 \\
\hline Belgium & 0.65 & 0.75 & 0.80 & 0.66 & 0.66 & 0.66 & 9.4 & 7.5 & 8.4 \\
\hline Canada & 0.75 & 0.80 & 0.80 & 0.63 & 0.63 & 0.64 & 8.9 & 7.8 & 8.6 \\
\hline Chile & $\mathrm{N} / \mathrm{A}$ & $\mathrm{N} / \mathrm{A}$ & 0.78 & $\mathrm{~N} / \mathrm{A}$ & 0.63 & $\mathrm{~N} / \mathrm{A}$ & $\mathrm{N} / \mathrm{A}$ & 9.0 & 13.0 \\
\hline Denmark & 0.85 & 0.95 & 0.80 & $\mathrm{~N} / \mathrm{A}$ & 0.55 & 0.52 & $\mathrm{~N} / \mathrm{A}$ & 8.8 & 7.6 \\
\hline Finland & 0.80 & 0.85 & 0.80 & 0.61 & 0.65 & 0.62 & 16.4 & 15.3 & 10.1 \\
\hline France & 0.80 & 0.80 & 0.80 & 0.57 & 0.53 & 0.54 & 8.9 & 8.4 & 9.8 \\
\hline Germany & 0.65 & 0.65 & 0.80 & 0.43 & 0.43 & 0.41 & 22.3 & 18.0 & 15.7 \\
\hline Hong Kong & $\mathrm{N} / \mathrm{A}$ & 0.90 & 0.70 & 0.18 & 0.33 & 0.47 & $\mathrm{~N} / \mathrm{A}$ & 21.8 & 34.0 \\
\hline Ireland & 0.80 & 0.90 & 0.80 & $\mathrm{~N} / \mathrm{A}$ & 0.77 & 0.79 & 9.6 & 9.0 & 9.1 \\
\hline Israel & 0.50 & 0.70 & $\mathrm{~N} / \mathrm{A}$ & 0.70 & $\mathrm{~N} / \mathrm{A}$ & 0.80 & $\mathrm{~N} / \mathrm{A}$ & 19.0 & 25.1 \\
\hline Italy & 0.50 & 0.56 & 0.60 & 0.63 & 0.67 & 0.73 & 17.2 & 14.4 & 10.7 \\
\hline Japan & $\mathrm{N} / \mathrm{A}$ & 0.60 & 0.55 & 0.60 & 0.62 & 0.60 & 22.2 & 22.1 & 20.4 \\
\hline Korea & 0.30 & 0.40 & 0.40 & 0.59 & 0.52 & 0.52 & 41.6 & 42.4 & 32.3 \\
\hline Malaysia & 0.65 & $\mathrm{~N} / \mathrm{A}$ & 0.85 & $\mathrm{~N} / \mathrm{A}$ & $\mathrm{N} / \mathrm{A}$ & 0.67 & $\mathrm{~N} / \mathrm{A}$ & 21.9 & 24.2 \\
\hline Netherlands & 0.75 & 0.75 & 0.75 & 0.48 & 0.46 & 0.51 & 12.2 & 9.5 & 11.0 \\
\hline New Zealand & 0.66 & 0.80 & 0.80 & $\mathrm{~N} / \mathrm{A}$ & 0.71 & 0.73 & 7.4 & 7.0 & 8.8 \\
\hline Norway & 0.75 & 0.80 & 0.80 & 0.74 & 0.78 & 0.76 & 13.8 & 13.6 & 9.6 \\
\hline Singapore & $\mathrm{N} / \mathrm{A}$ & $\mathrm{N} / \mathrm{A}$ & 0.85 & $\mathrm{~N} / \mathrm{A}$ & 0.90 & 0.88 & $\mathrm{~N} / \mathrm{A}$ & 32.4 & 43.2 \\
\hline Spain & 0.60 & 0.80 & 0.80 & 0.74 & 0.73 & 0.78 & 10.3 & 10.6 & 13.2 \\
\hline Sweden & 0.90 & 0.95 & 0.75 & 0.50 & 0.54 & 0.60 & 15.1 & 11.2 & 9.6 \\
\hline Switzerland & $\mathrm{N} / \mathrm{A}$ & $\mathrm{N} / \mathrm{A}$ & 0.90 & 0.30 & 0.31 & $\mathrm{~N} / \mathrm{A}$ & $\mathrm{N} / \mathrm{A}$ & 36.5 & 27.1 \\
\hline Taiwan & 0.40 & $\mathrm{~N} / \mathrm{A}$ & $\mathrm{N} / \mathrm{A}$ & 0.77 & 0.78 & 0.84 & 7.2 & 7.6 & 4.5 \\
\hline Thailand & 0.65 & $\mathrm{~N} / \mathrm{A}$ & 0.75 & 0.89 & 0.86 & 0.82 & 17.4 & 16.5 & 29.4 \\
\hline UK & 0.81 & 0.87 & 0.95 & 0.56 & 0.61 & 0.67 & 10.4 & 10.6 & 8.6 \\
\hline US & 0.80 & 0.89 & 0.80 & 0.66 & 0.64 & 0.65 & 7.4 & 7.3 & 6.9 \\
\hline
\end{tabular}


Table 3: Housing Price Dynamics

The dependent variable is $\Delta \log ($ Price), the log change in the real housing price index. $\Delta \log ($ Income $)$ is the log change in real per capita GDP. Price $t_{-1} /$ Income $_{t-1}$ is the start-of-period ratio of the real housing price index to real per capita GDP. Real interest rate is the nominal long-term interest rate on a government bond (usually 10-year benchmark government bond yield), from the IMF's International Financial Statistics or from the OECD's Economic Outlook, minus the inflation rate in the same year. Inflation rate is the change in the consumer price index for the current year, taken from the IMF's International Financial Statistics. The estimation period is 1970-1999. The estimations correct the error structure for heterosckedasticity using the White-Hubber estimator. $t$-stats (in parentheses).

\begin{tabular}{|c|c|c|c|c|c|c|c|}
\hline$\Delta \log (\text { Income })_{t}$ & $\begin{array}{l}1.187 \\
(9.07)^{* * *}\end{array}$ & $\begin{array}{l}0.942 \\
(6.61)^{* * *}\end{array}$ & $\begin{array}{l}0.942 \\
(6.36)^{* * *}\end{array}$ & $\begin{array}{l}1.125 \\
(7.17)^{* * *}\end{array}$ & $\begin{array}{l}1.061 \\
(6.94)^{* * *}\end{array}$ & $\begin{array}{l}1.009 \\
(7.13)^{* * *}\end{array}$ & $\begin{array}{l}1.022 \\
(7.49)^{* * *}\end{array}$ \\
\hline$\Delta \log (\text { Income })_{t-1}$ & & $\begin{array}{l}0.510 \\
(3.38)^{* * *}\end{array}$ & $\begin{array}{l}0.409 \\
(2.52)^{* * *}\end{array}$ & $\begin{array}{l}0.555 \\
(3.47)^{* * *}\end{array}$ & $\begin{array}{l}0.214 \\
(1.44)\end{array}$ & $\begin{array}{l}0.356 \\
(2.40)^{* *}\end{array}$ & \\
\hline$\Delta \log (\text { Price })_{t-1}$ & & & $\begin{array}{l}0.241 \\
(3.33)^{* * *}\end{array}$ & $\begin{array}{l}0.193 \\
(2.61)^{* * *}\end{array}$ & $\begin{array}{l}0.347 \\
(4.84)^{* * *}\end{array}$ & $\begin{array}{l}0.278 \\
(3.76)^{* * *}\end{array}$ & $\begin{array}{l}0.348 \\
(5.34)^{* * *}\end{array}$ \\
\hline$\Delta \log (\text { Price })_{t-2}$ & & & $\begin{array}{l}-0.099 \\
(-1.62)\end{array}$ & $\begin{array}{l}-0.111 \\
(-1.80)^{*}\end{array}$ & $\begin{array}{l}-0.169 \\
(-2.46)^{* * *}\end{array}$ & $\begin{array}{l}0.045 \\
(0.85)\end{array}$ & \\
\hline Interest Rate & & & & & $\begin{array}{l}-0.289 \\
(-2.41)^{* *}\end{array}$ & & \\
\hline$\sum_{j=0}^{2} \Delta \log (\text { Income })_{t-j}$ & & 1.700 & 1.434 & 2.022 & 1.446 & 1.541 & \\
\hline $\begin{array}{l}\text { Summation Test } p \text {-value } \\
\text { Exclusion Test } p \text {-value }\end{array}$ & & $\begin{array}{l}0.00 \\
0.00\end{array}$ & $\begin{array}{l}0.00 \\
0.00\end{array}$ & $\begin{array}{l}0.00 \\
0.00\end{array}$ & $\begin{array}{l}0.00 \\
0.00\end{array}$ & $\begin{array}{l}0.00 \\
0.00\end{array}$ & \\
\hline Country Effects? & No & No & No & Yes & No & Yes & Yes \\
\hline Year Effects? & Yes & Yes & Yes & Yes & Yes & Yes & Yes \\
\hline $\begin{array}{l}\text { Observations } \\
\text { Adj- } R^{2}\end{array}$ & $\begin{array}{c}718 \\
0.226\end{array}$ & $\begin{array}{c}679 \\
0.265\end{array}$ & $\begin{array}{c}666 \\
0.310\end{array}$ & $\begin{array}{c}666 \\
0.317\end{array}$ & $\begin{array}{c}616 \\
0.381\end{array}$ & $\begin{array}{c}666 \\
0.408\end{array}$ & $\begin{array}{c}692 \\
0.378\end{array}$ \\
\hline
\end{tabular}

***,**,* indicate statistical significance at $1 \%, 5 \%$, and $10 \%$ (two-tail) test levels, respectively. 


\section{Table 4: House Prices and the Multiplier Effect: Baseline Regressions}

The dependent variable is $\Delta \log ($ Price $)$, the log change in the real housing price index. $\Delta \log ($ Income $)$ is the log change in real per capita GDP. Price $t_{-1} /$ Income $_{t-1}$ is the start-of-period ratio of the real housing price index to real per capita GDP. Real interest rate is the nominal long-term interest rate on a government bond (usually 10-year benchmark government bond yield), from the IMF's International Financial Statistics or from the OECD's Economic Outlook, minus the inflation rate in the same year. Inflation rate is the change in the consumer price index for the current year, taken from the IMF's International Financial Statistics. LTV $V_{t}$ is the maximum LTV ratio for year $t$. The estimation period is 1970-1999. The estimations correct the error structure for heterosckedasticity using the White-Hubber estimator. $t$-stats (in parentheses).

\begin{tabular}{|c|c|c|c|c|c|}
\hline Indep. Variables & (1) & $(2)$ & (3) & (4) & $(5)$ \\
\hline$\Delta \log (\text { Income })_{t}$ & $\begin{array}{l}-0.437 \\
(-0.96)\end{array}$ & $\begin{array}{l}-0.787 \\
(-1.31)\end{array}$ & $\begin{array}{l}-0.622 \\
(-1.00)\end{array}$ & $\begin{array}{l}-0.273 \\
(-0.42)\end{array}$ & $\begin{array}{l}0.051 \\
(0.10)\end{array}$ \\
\hline$\Delta \log (\text { Income })_{t-1}$ & & $\begin{array}{l}1.174 \\
(1.11)\end{array}$ & $\begin{array}{l}1.029 \\
(1.03)\end{array}$ & $\begin{array}{l}0.132 \\
(0.17)\end{array}$ & \\
\hline$\Delta \log (\text { Income })_{t-2}$ & & $\begin{array}{l}-0.470 \\
(-0.62)\end{array}$ & $\begin{array}{l}-0.199 \\
(-0.24)\end{array}$ & $\begin{array}{l}0.504 \\
(0.91)\end{array}$ & \\
\hline$\Delta \log (\text { Price })_{t-1}$ & & $\begin{array}{l}0.228 \\
(3.01)^{* * *}\end{array}$ & $\begin{array}{l}0.174 \\
(2.08)^{* *}\end{array}$ & $\begin{array}{l}0.299 \\
(4.21)^{* * *}\end{array}$ & $\begin{array}{l}0.332 \\
(4.88)^{* * *}\end{array}$ \\
\hline$\Delta \log (\text { Price })_{t-2}$ & & $\begin{array}{l}-0.070 \\
(-1.35)\end{array}$ & $\begin{array}{l}-0.081 \\
(-1.47)\end{array}$ & $\begin{array}{l}-0.089 \\
(-1.71)^{*}\end{array}$ & \\
\hline Interest Rate & & & & $\begin{array}{l}-0.287 \\
(-1.39)\end{array}$ & \\
\hline Inflation Rate & & & & $\begin{array}{l}-0.092 \\
(-0.69)\end{array}$ & \\
\hline Price $_{t-1} /$ Income $_{t-1}$ & & & & & $\begin{array}{l}-0.231 \\
(-8.71)^{* * *}\end{array}$ \\
\hline$L T V_{t}$ & $\begin{array}{l}-0.065 \\
(-1.52)\end{array}$ & $\begin{array}{l}-0.037 \\
(-0.81)\end{array}$ & $\begin{array}{l}-0.214 \\
(-2.40)^{* *}\end{array}$ & $\begin{array}{l}0.007 \\
(0.16)\end{array}$ & $\begin{array}{l}-0.068 \\
(-0.82)\end{array}$ \\
\hline$\Delta \log (\text { Income })_{t} \times L T V_{t}$ & $\begin{array}{l}2.276 \\
(3.58)^{* * *}\end{array}$ & & & & $\begin{array}{l}1.315 \\
(1.80)^{*}\end{array}$ \\
\hline $\begin{aligned} & \sum_{j=0}^{2} \Delta \log (\text { Income })_{t-j} \\
& \times L T V_{t}\end{aligned}$ & & $\begin{array}{l}2.152 \\
(2.45)^{* * *}\end{array}$ & $\begin{array}{l}2.414 \\
(1.95)^{* *}\end{array}$ & $\begin{array}{l}1.420 \\
(1.75)^{*}\end{array}$ & \\
\hline Country Effects? & No & No & Yes & No & Yes \\
\hline Year Effects? & Yes & Yes & Yes & Yes & Yes \\
\hline $\begin{array}{l}\text { Observations } \\
\text { Adj- } R^{2}\end{array}$ & $\begin{array}{c}611 \\
0.220\end{array}$ & $\begin{array}{c}567 \\
0.297\end{array}$ & $\begin{array}{c}567 \\
0.316\end{array}$ & $\begin{array}{c}531 \\
0.342\end{array}$ & $\begin{array}{c}589 \\
0.362\end{array}$ \\
\hline
\end{tabular}


Table 5: House Prices and the Multiplier Effect: Alternative Specifications

The dependent variable in columns (1) through (7) is $\Delta \log ($ Price), the log change in real housing price index. $\Delta \log ($ Income $)$ is the log change in real per capita GDP. Price $t_{-1} /$ Income $_{t-1}$ is the start-of-period ratio of the real housing price index to real per capita GDP. In columns (1) and (2) we instrument $L T V_{t}$ with proxies for the quality of accounting standards and judicial efficiency. Judicial efficiency is an assessment of the efficiency and integrity of the legal environment as it affects business, compiled by the Business International Corporation, taken from LaPorta et al. (1998). Acounting standards is the index of accounting standards computed by the Center for International Financial Analysis and Research, data from LaPorta et al. (1998). In columns (3) and (4) we control for the level of economic development (PPP-ajusted per capita GDP) by including the intercept variable as well as its interactions with each of the lags of $\Delta \log ($ Income) (coefficients omitted). Likewise, in columns (5) and (6) we add intercept and interaction terms for homeownership and $\Delta \log ($ Income). The data for per capita GDP in constant prices is from Penn World Tables, taken from the Barro and Lee (1994) dataset, and augmented with data from the Global Development Finance \& World Development Indicators. The homeownership ratio is the proportion of homeowners as a fraction of total households. In column (7) we use the GMM estimator for dynamic panel data proposed by Arellano and Bond (1991). The estimation period is 1970-1999. The OLS estimations correct the error structure for heterosckedasticity using the White-Hubber estimator. $t$-stats (in parentheses).

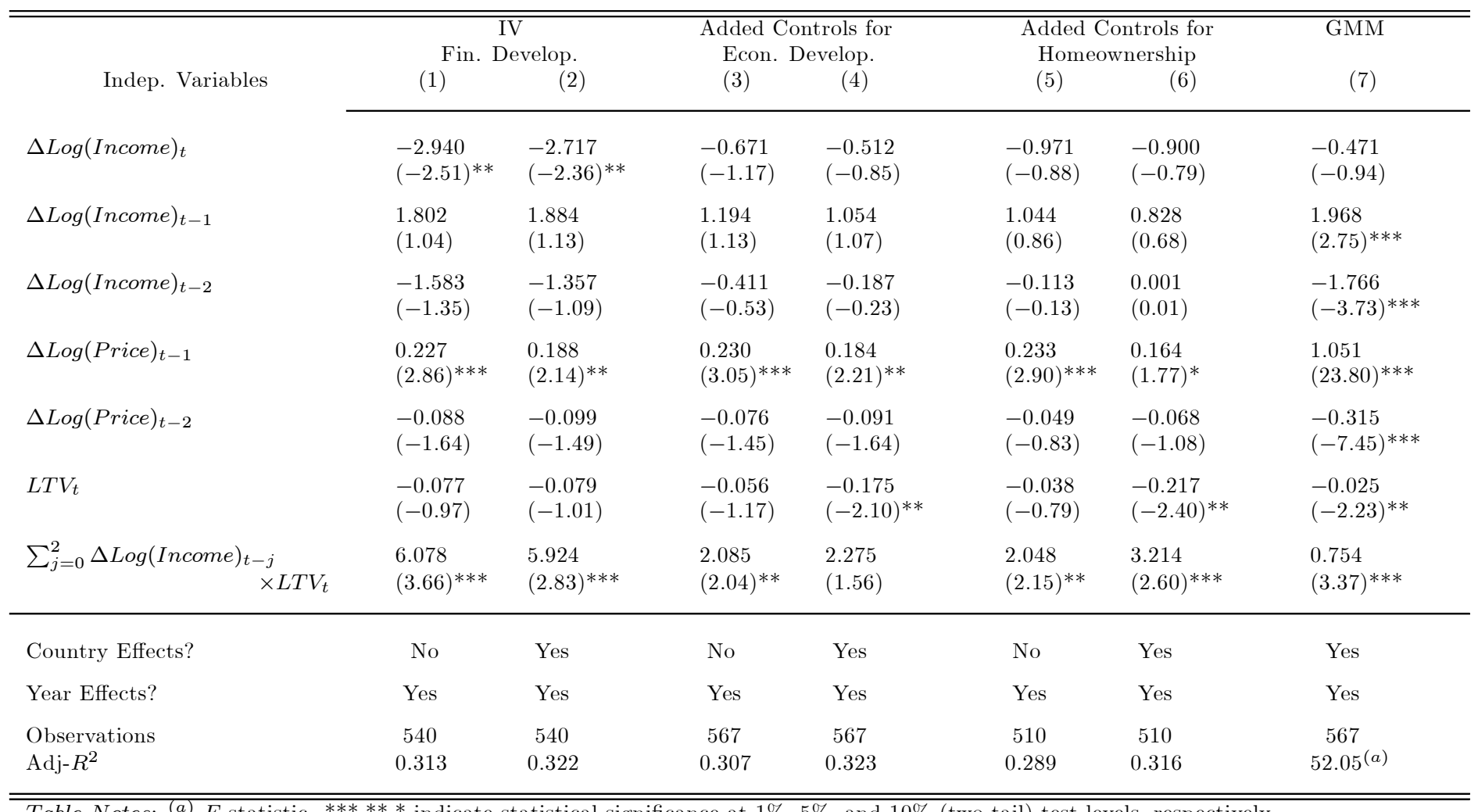

Table Notes: ${ }^{(a)}$ F-statistic. ${ }^{* * *},{ }^{* *},{ }^{*}$ indicate statistical significance at $1 \%, 5 \%$, and $10 \%$ (two-tail) test levels, respectively. 
Table 6: The Multiplier Effect in New Mortgages

The dependent variable in columns (1) through (6), New Mortgages, is the net new lending against mortgage in residential property divided by GDP. $\Delta \log \left(\right.$ Income) is the log change in real per capita GDP. Price t-1 $_{1} /$ Income $_{t-1}$ is the start-of-period ratio of the real housing price index to real per capita GDP. $L T V$ is the maximum loan-to-value ratio. The estimation period is 1970-1999. The OLS estimations correct the error structure for heterosckedasticity using the White-Hubber estimator. $t$-stats (in parentheses).

\begin{tabular}{|c|c|c|c|c|c|c|}
\hline Indep. Variables & (1) & $(2)$ & (3) & $(4)$ & $(5)$ & $(6)$ \\
\hline$\Delta \log (\text { Income })_{t}$ & $\begin{array}{c}-0.572^{*} \\
(-1.72)\end{array}$ & $\begin{array}{c}-0.540^{*} \\
(-1.67)\end{array}$ & $\begin{array}{c}-0.632^{*} \\
(-1.82)\end{array}$ & $\begin{array}{c}-0.584^{*} \\
(-1.75)\end{array}$ & $\begin{array}{l}-0.588 \\
(-1.59)\end{array}$ & $\begin{array}{c}-0.834^{* *} \\
(-2.22)\end{array}$ \\
\hline$\Delta \log (\text { Income })_{t-1}$ & & & $\begin{array}{l}0.266 \\
(0.86)\end{array}$ & $\begin{array}{l}0.195 \\
(0.82)\end{array}$ & $\begin{array}{l}0.137^{*} \\
(1.82)\end{array}$ & $\begin{array}{c}0.130^{*} \\
(1.89)\end{array}$ \\
\hline$\Delta \log (\text { Income })_{t-2}$ & & & $\begin{array}{l}-0.219 \\
(-0.64)\end{array}$ & $\begin{array}{l}-0.176 \\
(-0.63)\end{array}$ & & \\
\hline Price $_{t-1} /$ Income $_{t-1}$ & & & & & $\begin{array}{c}0.027^{* * *} \\
(4.53)\end{array}$ & $\begin{array}{c}0.039^{* * *} \\
(3.83)\end{array}$ \\
\hline$L T V_{t}$ & $\begin{array}{c}0.054^{* *} \\
(4.40)\end{array}$ & $\begin{array}{c}0.063^{* * *} \\
(2.82)\end{array}$ & $\begin{array}{c}0.052^{* * *} \\
(3.88)\end{array}$ & $\begin{array}{c}0.059^{* * *} \\
(2.62)\end{array}$ & $\begin{array}{c}0.042^{* * *} \\
(3.15)\end{array}$ & $\begin{array}{c}0.040^{* * *} \\
(2.69)\end{array}$ \\
\hline$\Delta \log (\text { Income })_{t} \times L T V_{t}$ & $\begin{array}{c}0.997^{* *} \\
(2.28)\end{array}$ & $\begin{array}{c}0.933^{* *} \\
(2.08)\end{array}$ & & & $\begin{array}{c}1.049^{* * *} \\
(2.85)\end{array}$ & $\begin{array}{c}1.020^{* * *} \\
(2.57)\end{array}$ \\
\hline $\begin{aligned} \sum_{j=0}^{2} \Delta \log (\text { Income })_{t-j} & \\
& \times L T V_{t}\end{aligned}$ & & & $\begin{array}{r}0.947^{*} \\
(1.85)\end{array}$ & $\begin{array}{l}0.765 \\
(1.48)\end{array}$ & & \\
\hline Country Effects? & No & Yes & No & Yes & No & Yes \\
\hline Year Effects? & Yes & Yes & Yes & Yes & Yes & Yes \\
\hline $\begin{array}{l}\text { Observations } \\
\text { Adj- } R^{2}\end{array}$ & $\begin{array}{c}271 \\
0.206\end{array}$ & $\begin{array}{c}271 \\
0.509\end{array}$ & $\begin{array}{c}265 \\
0.231\end{array}$ & $\begin{array}{c}265 \\
0.512\end{array}$ & $\begin{array}{c}268 \\
0.287\end{array}$ & $\begin{array}{c}268 \\
0.560\end{array}$ \\
\hline
\end{tabular}

Table Notes: ${ }^{* * *},{ }^{* *},{ }^{*}$ indicate statistical significance at $1 \%, 5 \%$, and $10 \%$ (two-tail) test levels, respectively. 
Table 7: The Income Constraint Effect

For each country, we use the average price-income ratio for the period 1970-1999 (subject to data availability) to classify countries in the "cheap" and "expensive" categories. The price-income ratio is the nominal price of a typical home divided by personal disposable income percapita. Cheap (expensive) housing countries are those ranked in the bottom (top) third of the cross-country distribution of the ratio of house prices to per capita GDP. The countries in the cheap housing category are: Australia, Belgium, Canada, Denmark, France, Netherlands, New Zealand, Tawain, and the US.

The expensive housing countries are: Hong Kong, Israel, Japan, Korea, Malaysia, Singapore, Switzerland, and Thailand. The estimation period is 1970-1999. The baseline-OLS specification is the one in column (3) of Table 4, including three lags of income and housing price changes, as well as the interactions of the LTV ratio with the income changes. The baseline-GMM specification uses the GMM estimator for dynamic panel data proposed by Arellano and Bond (1991), as in column (7) of Table 4. The Lamont and Stein specification is the one in column (5) of Table 4, which includes the current change in per capita GDP and its interaction with the LTV ratio. The OLS estimations correct the error structure for heterosckedasticity using the White-Hubber estimator. $t$-stats (in parentheses).

\begin{tabular}{|c|c|c|c|}
\hline & $\begin{array}{c}\text { Baseline-OLS } \\
\sum_{j=0}^{2} \Delta \log (\text { Income })_{t-j} \times L T V_{t}\end{array}$ & $\begin{array}{c}\text { Baseline-GMM } \\
\sum_{j=0}^{2} \Delta \log (\text { Income })_{t-j} \times L T V_{t}\end{array}$ & $\begin{array}{c}\text { Lamont-Stein } \\
\Delta \log (\text { Income })_{t} \times L T V_{t}\end{array}$ \\
\hline Cheap Housing Countries & $\begin{array}{l}8.497 \\
(1.64)^{*}\end{array}$ & $\begin{array}{l}2.808 \\
(2.59)^{* * *}\end{array}$ & $\begin{array}{l}9.742 \\
(3.92)^{* * *}\end{array}$ \\
\hline Expensive Housing Countries & $\begin{array}{l}2.508 \\
(1.38)\end{array}$ & $\begin{array}{l}0.227 \\
(0.45)\end{array}$ & $\begin{array}{l}1.001 \\
(0.93)\end{array}$ \\
\hline
\end{tabular}

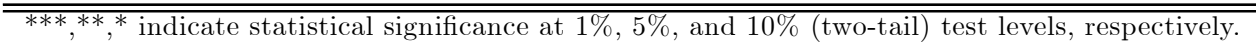


Figure 1: Impulse-Response Functions

This figure shows the response of new mortgages to a one-standard-deviation shock to per capita GDP. The estimates come from a two-lag VAR system that also includes changes in log CPI and interest rates (all variables are standardized). Panel A plots results for data from Italy and Panel B uses US data. The system is estimated with yearly series from 1975 through 1999.

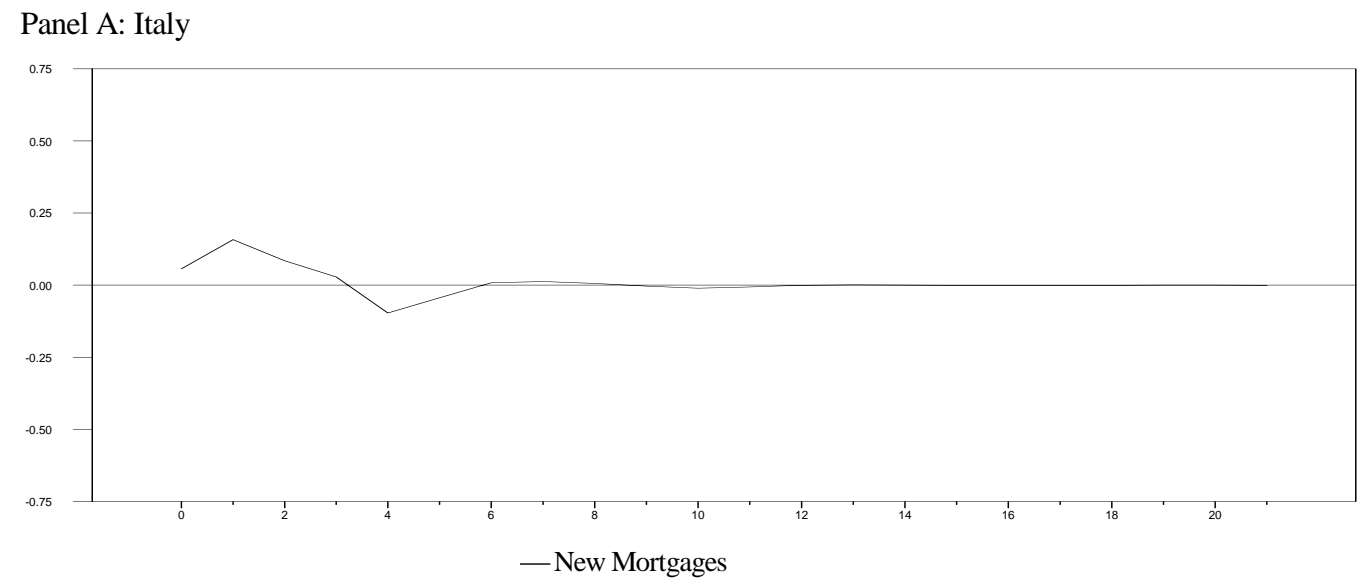

Panel B: US

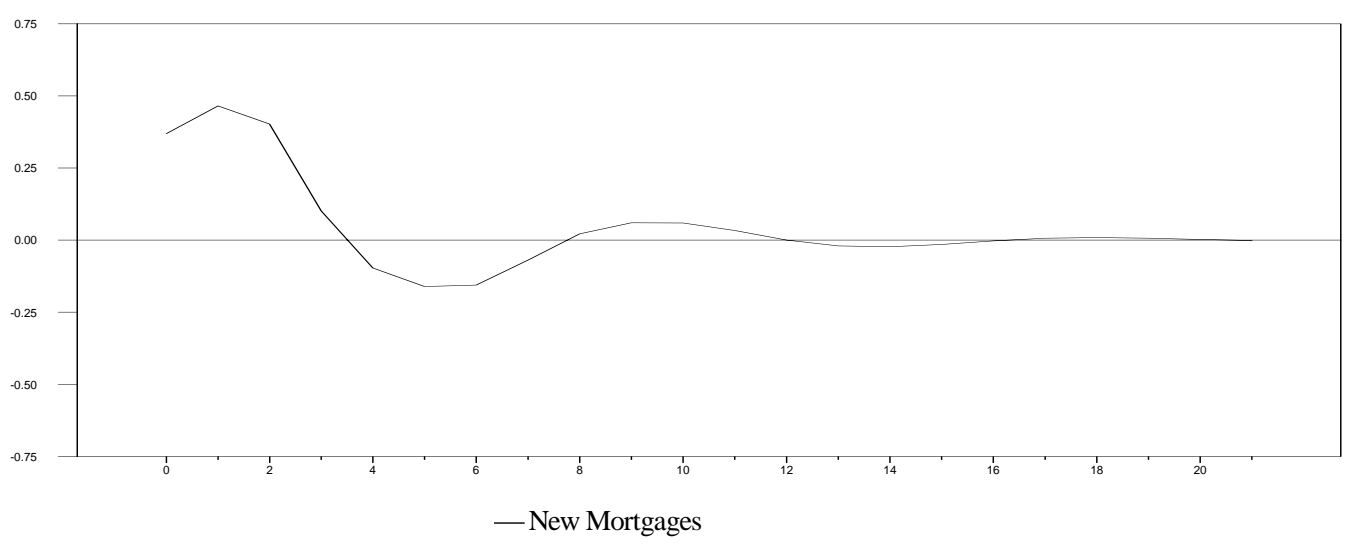

